\title{
Hedonisme dan Pola Hidup Islam
}

\author{
Maryam Ismail \\ e-mail: maryam.ismail@umi.ac.id \\ Dosen Tetap Fakultas Agama Islam Universitas Muslim Indonesia
}

\begin{abstract}
Abstrak
Hedonisme merupakan sebuah pandangan hidup yang menyatakan kesenangan untuk menikmati segalanya adalah tujuan hidup manusia di dunia ini. Kondisi hedonisme banyak ditemukan bukan hanya pada pelajar, dan anak-anak muda atau mahasiswa, nampaknya sudah menyeluruh dalam berbagai kalangan masyarakat. Awalnya hanya kebanyakan dari orang-orang berduit yang selalu memperhatikan penampilan luar dan menikmati hidup ini dengan sepuasnya, bergaul, makan, jalan-jalan, bersenang-senang, berpoya-poya akhirnya sudah menular kepada yang lain meskipun dalam kondisi hidup kekurangan. Pandangan Hedonisme muncul sebagai jawaban dari pertanyaan Socrates tentang tujuan hidup adalah mencari kenikmatan dan kesenangan, tetapi bukan berarti rakus dan memiliki harta sebanyakbanyaknya. Paham ini perlu diwaspadai, karena bisa merusak gaya hidup seseorang dengan menghalalkan segala cara untuk kenikmatan dan kesenangan saja. Sementara kebahagiaan dalam ajaran Islam bukan hanya mengejar kebahagiaan dan kenikmatan lahir yang sesaat, tetapi kebahagiaan adalah keseimbangan lahir dan batin yang dapat dinikmati dunia dan akhirat setelah berhasil mendapatkan ridha Allah Swt. Di dunia yang lebih penting beramal saleh dengan jalan memperbaiki hubungan dengan Allah Swt dan kepada sesama manusia serta seluruh makhlukNya.
\end{abstract}

Kata kunci:

\section{PENDAHULUAN}

A. Latar Belakang.

Kesuksesan di zaman sekarang ini kebanyakan diukur dengan seberapa banyak seseorang menguasai harta kekayaan, dinikmati tanpa melihat asal muasal harta yang didapat. Hedonisme dan materialistik sebagai gaya hidup yang sedang banyak diperbincangkan zaman ini. Padahal paham hedonisme sendiri sebenarnya merupakan paham yang sudah usang, yakni berasal dari Yunani Kuno yang salah satu tokohnya adalah Epikurus yang hidup antara tahun 341 sampai dengan 271M. sebagai jawaban dari pertanyaan gurunya tentang kebahagiaan yang menjadi tujuan hidup manusia.

Pola hidup untuk bersenang-senang atau gaya hidup yang menjadi tujuan utama sebuah kenikmatan dan kebahagiaan diri sendiri. Sebagian besar masyarakat mendeskripsikan sebagai gaya hidup "hedonisme" sebuah perilaku konsumtif atau konsumerisme yang berdampak buruk bagi penganutnya. Tentu saja gaya hidup tidak muncul begitu saja namun dipengaruhi faktor internal dan eksternal. Sedari kecil terlalu dimanjakan orangtua, diberi berbagai fasilitas atau kemudahan sehingga merasa selalu mendapatkan apa yang diinginkan tanpa mempedulikan neraca kebutuhan, dan faktor lainnya.

Hedonisme adalah pandangan hidup yang menganggap bahwa orang akan menjadi bahagia dengan mencari harta sebanyak mungkin dan menghindari perasaan-perasaan yang menyakitkan. Hedonisme merupakan ajaran atau pandangan bahwa kesenangan atau kenikmatan merupakan tujuan hidup dan tindakan manusia.Terdapat tiga aliran pemikiran dalam hedonis yakni Cyrenaics, Epikureanisme, dan Utilitarianisme. (Franz Magnis-Suseno.1987:114).

DOI:xxx-

Jurnal Ilmiah Islamic Resources FAI-UMI Makassar | 193 
Kehadiran 'influencer' di media sosial sangat mempengaruhi rasa kecemburuan untuk memiliki benda-benda mewah yang sebenarnya tidak sanggup untuk didapatkan sehingga memaksakan segala cara meskipun harus berutang. Pergaulan atau bergaul dengan orang-orang yang memiliki standar hidup mewah, menggunakan barang-barang bermerek, sehingga muncul rasa minder ketika tidak sepadan dengan mereka. Akhirnya demi mengikuti pergaulan tersebut mereka rela menghabiskan uang untuk membeli barang yang sama.

Disisi lain kehadiran ajaran Islam mengajarkan manusia tentang kebahagiaan abadi yang menyeimbankang rohani dan jasmani, dunia dan akhirat. Hidup bukan hanya diperoleh dari kehidupan memuaskan keinginan-keinginan sesaat. Kebahagiaan terletak pada kesanggupan mengendalikan diri dari dorongan sifat-sifat buruk dan negative atau mengendalikan hawa nafsu.

\section{B. PERMASALAHAN}

1. Mengapa paham hedonisme telah menjadi gaya hidup manusia dewasa ini?

2. Bagaimana pandangan ajaran Islam tentang pola hidup Hedonisme?

3. Bagaimana mencegah dampak buruk Hedonisme?

\section{A. Munculnya Ajaran Hedonisme}

\section{PEMBAHASAN}

\section{Pengertian Hedonism}

Kata hedonisme sudah muncul sejak awal munculnya filsafat, atau saat manusia mulai berfilsafat pada tahun 433 Sebelum Masehi. Epikuros lahir tahun 342 SM di kota Samos, Yunani, dan meninggal di Atena tahun 270 SM-(Albert E. Avey: 1954: 23). Paham ini muncul ketika Socrates, salah satu filsuf paling terkenal mempertanyakan tentang tujuan hidup manusia di dunia ini. Pertanyaan tersebut akhirnya melahirkan pandangan hedonism sebagai jawaban dari muridnya. Pada masa itu hedonisme bukan untuk menggambarkan perilaku negatif, melainkan untuk mendeskripsikan esensi dari eksistensial manusia di muka bumi berbeda makhluk yang lain. Jawaban atas pertanyaan Socrates kemudian menjadi pandangan hedonisme yang berawal dari pemikiran beberapa filsuf lainnya, seperti Aristippus dan Epikuros. Kedua filsuf ini memiliki pandangan berbeda terhadap hedonismeos. Aristippus menggambarkan semua kesenangan manusia bersifat fisik, selanjutnya berbagai orang yang mendeskripsikan pemikiran ini di masamasa modern pada akhirnya memiliki pandangan dengan garis besar yang sama, bahwa hedonisme adalah pandangan seseorang yang berusaha hidup untuk mencari kesenangan sebagai tujuan paling penting, terutama untuk dirinya sendiri.

Dalam kamus Al-Munawwir disebutkan sebagai berikut: Hedonisme adalah sebuah aliran yang mengatakan bahwa sesungguhnya kelezatan dan kebahagiaan adalah tujuan utama dalam hidup. Kemudian dalam Ensiklopedia Bahasa Indonesia disebutkan bahwa Hedonisme adalah paham yang berpendapat bahwa kepuasan merupakan satu-satunya alasan dalam tindak susila. Hedonisme adalah pandangan hidup yang menganggap bahwa orang akan menjadi bahagia dengan mencari kebahagiaan sebanyak mungkin dan sedapat mungkin menghindari perasaanperasaan yang menyakitkan. ( Franz Magnis-Suseno:1987:114).

Beberapa ahli memberikan pandangannya terhadap pemahaman fenomena hedonisme adalah antara lain sebagai berikut:

a. Frans Magnis Suseno 
Definisi hedonisme menurut Frans, adalah pandangan hidup yang menganggap individu akan menjadi atau merasa bahagia dengan mencari kebahagiaan sebanyak mungkin serta sebisa mungkin menghindari atau menekan perasaan-perasaan yang menyakitkan.

b. Sarwono

Hedonisme ialah konsep diri, di mana gaya hidup seseorang dilakukan sesuai dengan gambaran yang ada dipikirannya.

c. Burhanuddin

Hedonisme, sesuatu yang mendatangkan kesenangan kalau hanya mendatangkan kesusahan, penderitaan, dan tidak menyenangkan adalah hal yang dinilai tidak baik.

Collins Gem

Dalam pandangan Gem, istilah hedonisme ini merupakan suatu doktrin yang menyatakan bahwa kesenangan adalah hal yang paling penting dalam hidup. Oleh karena itu, paham ini dianut oleh orang-orang yang mencari kesenangan dalam hidup semata.

2. Pandangan Hidup Hedonisme

Konsep moral dari hedonisme menyamakan kebaikan dengan kesenangan. Jadi semua kesenangan dan kenikmatan secara fisik selalu membawa kebaikan. Pandangan hidup ini mengajarkan bahwa pemujaan terhadap kesenangan dan kenikmatan dunia harus dikejar, dan itulah tujuan hidup yang paling hakiki bagi manusia. Pandangan hidup seperti yang banyak dan hampir semua umat manusia menerima dan menjadikannya sebagai tolok ukur dalam gaya hidup. Teori ini juga cenderung mengajarkan, bahwa untuk mendapat kesenangan dan kenikmatan serta kebahagiaan, tidak perlu menunggu di surga, karna manusia setelah mati tammatlah riwayatnya dan kalimat yang sering diucapkan oleh para hedonis:" kita tidak perlu pergi kesurga untuk mengalami kebahagiaan, karena di dunia, kenikmatan dan kebahagiaan serta kesenangan telah tersedia untuk dinikmati.

Tujuan hidup menurut Epikuros adalah hedone, yaitu kenikmatan (Hadiwijono, 1980:56). Kenikmatan yang sesungguhnya dicapai dengan menjadi ataraxia, yakni ketenangan badan, pikiran, dan jiwa (Newberry, 1999:144). Dengan demikian kenikmatan dapat dicapai jika batin tenang dan badan sehat (Hadiwijono, 1980:56). Epikuros membahas tiga masalah yang mengganggu ketenangan: Pertama, ketakutan akan dewa-dewa. Kedua, ketakutan akan kematian. Ketiga, ketakutan akan masa depan atau nasib. Ketakutan-ketakutan tersebut menurut Epikurus adalah sebagai hal yang tidak berdasar. Para dewa, menurut Epikurus, jangan dianggap mirip dengan manusia yang diombang-ambingkan oleh segala emosi. Manusia jangan berpikiran bahwa "nasib" buruk itu disebabkan oleh para dewa. (Magnis-Suseno, 1997:64). Dewa-dewa itu ada tetapi tidak berperan terhadap manusia (Newberry, 1999:144). Dewa menurut Epikuros adalah pengada yang abadi dan bahagia. Minimal, ini adalah gambaraan umum yang dapat digariskan tentang dewa dan jangan mengkaitkan sesuatu dengan dewa yang bertentangan dengan keabadiannya atau tidak dapat disesuaikan dengan kebahagiaannya tetapi mempercayai dewa sebagai sesuatu yang dapat menjunjung tinggi keabadian dan kebahagiaannya (Newberry, 1999:145). Segala sesuatu di jagad raya ini terjadi karena gerak atom-atom. Dewa-dewa menikmati kebahagiaan yang kekal dan tidak bisa digannggu oleh siapa pun. Manusia tidak mungkin mengganggu dewa-dewa maka dewa-dewa pun tidak akan menggannggu manusia. Oleh karena itu, manusia tidak perlu takut terhadap dewa-dewa (Hadiwijono, 1980:55). Anggapan umum tentang dewa bukan dalam pengertian benar tentang dewa tetapi berdasar pada pemikiranpemikiran yang keliru (Newberry, 1999:145). 
Berdasarkan hal tersebut menunjukkan bahwa hedonisme Epikurus bukanlah ateistik karena tetap percaya pada dewa-dewa. Persoalannya adalah manusia takut pada dewa karena berpikiran bahwa dewa akan menghukum orang jahat dan mengganjar orang yang suci. Epikuros menolak common sense tersebut. Bagi Epikuros, manusia dan dewa memiliki wilayah yang berbeda. Dewa tidak berperan dalam kehidupan manusia (Newberry,1999:144). Epikuros juga berpandangan bahwa kematian tidak perlu ditakuti karena selama manusia masih hidup berarti manusia belum mati. Jika manusia mati berarti tidak ada lagi sehingga tidak merasakan apa-apa. Jika manusia hidup dengan baik maka akan mati dengan baik (Magnis-Suseno, 1997:64).

Menurut Epikurus kematian tidak memiliki arti, karena sesuatu yang baik dan buruk itu hanya berdasar perasaan, namun kematian justru berarti peniadaan perasaan. Pemahaman bahwa kematian tidak berarti apa-apa menjadikan hidup menyenangkan. Kematian karena mengerikan maka nikmati ketika masih hidup. Kematian menakutkan karena kita memikirkannya, bukan kematian itu sendiri yang menakutkan. Kebanyakan orang menganggap bahwa kematian adalah kejahatan besar, tetapi orang yang bijaksana tidak takut akan kematiannya. Kematian bagi kebanyakan orang sebagai hal yang buruk, tetapi di lain pihak merindukannya sebagai istirahat dari kepayahan hidup. Orang bijak tidak akan menolak hidup dan tidak takut terhadap keadaan ketika tidak hidup lagi. Orang yang bijaksana pada saat makan pun tidak harus mendapat sebanyak mungkin makanan, tetapi mengutamakan cara memasak yang baik. Orang bijak tidak merindukan hidup yang panjang, tetapi sesuatu yang paling menyenangkan. Dengan demikian hidup mesti dirindukan karena berarti melatih diri sehingga mampu mempertahankan hidup lebih baik yang berarti juga mempersiapkan kematian yang baik pula (Newberry, 1999:145).

Hidup sekarang sangat diintensifkan, energi jangan dihabiskan untuk memikirkan sesuatu yang tidak jelas. Hedonisme Epikuros tidak mengejar maksimalisasi tetapi kenikmatan (secukupnya). Hedonisme bukan seorang yang serakah tetapi pilih-pilih. Kebebasan dari gangguan adalah tujuan hidup yang membahagiakan. Kenikmatan adalah permulaan dan akhir kehidupan (MagnisSuseno, 1997:68).

Pemaparan di atas menunjukkan bahwa kenikmatan bagi Epikurus adalah sesuatu yang baik dan alami. Rasa nikmat yang menimbulkan tidak enak tidak perlu diambil. Nikmat tidak sama dengan rakus. Biasakanlah hidup penuh kesederhanaan. Kenikmatan adalah tujuan maka janganlah diperbudak. Kenikmatan bukan melulu sensualitas tetapi pembebasan dari rasa sakit badan dan jiwa (Magnis-Suseno, 1997:69). Jika manusia menyikapi keinginaan-keinginan dengan tenang maka berarti belajar memanfaatkan setiap keinginan untuk tujuan kesehatan badan dan pemeliharaan ketenangan jiwa (Newberry, 1999:145).

Kenikmatan bagi Epikuros adalah alpha dan omega. Kenikmatan merupakan nilai pertama yang dimiliki sejak manusia lahir. Nilai inilah yang selalu mengarahkan setiap usaha maupun sesuatu yang dihindari. Nilai kenikmatan merupakan nilai pertama dan alami, oleh karenanya tidak tertarik pada setiap kenikmatan, tetapi kadang-kadang membiarkan kenikmatan itu berlalu jika ada kekuatiran bahwa kenikmatan tersebut akan mengakibatkan perasaan tidak enak yang lebih besar. Bahkan menilai banyak perasaan sakit lebih tinggi daripada kenikmatan-kenikmatan, yakni jika masa penderitaan yang agak lama akan disusul oleh kesenangan yang lebih besar (MagnisSuseno, 1997:68). Orang bijak tahu seni untuk menikmati selama dan sedalam mungkin. Persaudaraan atau persahabatan menurut Epikuros dipandang penting sebagai sarana untuk mencapai kenikmatan (Hadiwijono, 1980:56). 
Epikurus menyatakan juga bahwa manusia tidak perlu takut dengan masa depan atau nasib. Manusia mengambil sikap terhadap apa yang dibawa masa depan, oleh karena itu sikap yang tepat mesti diusahakan. Epikurus mengajarkan pentingnya hidup dengan tepat (Magnis-Suseno, 1997:64). Manusia menguasai hidup dan setiap aktivitasnya. Atom dapat bergerak berubah arah sehingga kemungkinan perubahan memang ada. Manusia dapat mengubah pengungkapan kehendaknya, oleh karena itu manusia sendiri yang menentukan keadaan (Hadiwijono, 1980:56). Epikuros menunjukkan bahwa manusia mesti bersikap bijaksana terhadap keinginankeinginannya. Sesuatu yang diperhatikan adalah yang alami bukan yang aneh-aneh. Orang bijak akan hidup sedemikian rupa hingga ia sehat dan tenang jiwanya, karena pada dasarnya manusia hanya memerlukan dua hal untuk hidup bahagia, yakni kebebasan dari perasaan sakit badani dan perasaan takut dan resah (Magnis-Suseno, 1997:64-65)

Pada dasarnya memburu kesenangan menurut Epikurus tidak seperti yang dipahami hedonisme sekarang ini, nampaknya sudah terjadi pergeseran pemahaman. Hedonisme Epikurus tidak identik dengan rakus dan banyak harta, tetapi kenikmatan yang dimaksud adalah sesuatu yang menyenangkan dan manusia dapat terhindar dari kesulitan serta kesedihan. Berbeda dengan hedonisme zaman sekarang dilakukan dengan memperbanyak harta dan foya-foya memenuhi kebutuhan meskipun dengan memaksakan diri pada akhirnya membawa kesengsaraan atau penderitaan.

Walaupun demikian hedonisme yang dipahami sekarang ini telah mengalami pergeseran adalah menikmati hidup dengan memanjakan diri, bersenang-senang dengan memuaskan keinginan dengan mengumpulkan harta sebanyak-banyaknya tampa memperdulikan orang lain. Sukses dan berhasil ketika seseorang dapat mencapai kenikmatan dan merasa senang, tolok ukur kebaikan menghindari kesusahan atau yang menyakitkan. Sehingga penganut paham hedonisme melahirkan karakter sebagai berikut:

a. Konsumtif

b. Seseorang yang menggunakan ideologi hedonisme pasti cenderung gaya hidupnya menjadi konsumtif, yakni memenuhi nafsu atau keinginan maya semata, mengutamakan penampilan luar.

c. Materialis

d. Hedonisme menganggap uang segalanya dalam memfasilitasi kehidupan untuk mewujudkan semua keinginan, juga tidak pernah puas dengan apa yang telah dimiliki, bahkan bisa mengarah pada contoh penyimpangan sosial, yakni tindak kriminal

e. Cenderung lebih egois, dan dapat melakukan segala cara untuk memenuhi kesenangannya

f. walaupun akan merugikan orang lain.

g. Tidak memiliki empati terhadap lingkungan social, berusaha mencapai kesenangannya dengan segala cara. Melakukan rasionalisasi atau pembenaran atas kesenangan mereka apabila kesenangan tersebut bertentangan dengan norma-norma hukum dan social

Dari beberapa pendapat tentang hedonisme hanya menilai sisi negatifnya saja, bila dicermati pada awal munculnya pandangan ini, hedonisme bukanlah suatu hal yang benar-benar buruk. Mencari kesenangan dalam hidup bukanlah hal yang salah di kehidupan yang singkat ini. Namun bila mencari kesenangan dijadikan sebagai tujuan mutlak, maka seseorang tidak akan memiliki empati terhadap individu lainnya karena hanya berusaha terus menerus memenuhi kesenangan pribadi. Di sisi lain, perilaku hedonisme dapat memberikan sisi positif terhadap yang mempunyai sudut 
pandang ini., di antaranya dapat memanfaatkan segala kesempatan dengan baik, pantang menyerah dalam mencapai tujuan, dan memiliki motivasi yang kuat untuk mendapatkan apa yang diinginkan.

Selain itu hedonisme menyamakan antara kesenangan dengan kebaikan dan kebahagiaan, belum sampai pada pemikiran, bahwa kesenangan tidak selamanya mendatangkan kebahagiaan. Seharusnya ketika menjawab pertanyaan apakah tujuan hidup ini Epicurus memikirkan secara tuntas makna hakikat kesenangan. Jangan berhenti pada kesenangan lahiriyah semata secara spesipik. Kalau saja memikirkan kesenangan secara universal, kritis sesuai dengan kaidah logika akan sampai pada kesimpulan tentang tujuan hidup yaitu bukan hanya bersenang-senang sesaat.

3. Faktor Penyebab Hedonisme

Ada 2 faktor penyebab perpindahan hedonisme yaitu faktor internal dan faktor eksternal.

a) Faktor Internal

Faktor internal, dari diri sendiri merupakan penyebab hedonisme yang paling utama. Sudah menjadi sifat dasar manusia yang ingin bersenang-senang dengan bekerja keras. Selain itu, manusia juga memiliki sifat dasar yang tidak pernah puas dengan hal yang sudah dimiliki. Sifat dasar manusia tersebutlah yang menjadi penyebab hedonisme dan juga perilaku konsumerisme.

b) Faktor Eksternal

Faktor penyebab hedonisme dari luar yang paling utama adalah arus informas dari luar yang sangat besar atau globalisasi. Kebiasaan dan paham orang dari luar negeri yang dianggap bisa membuat senang lalu diadaptasi oleh masyarakat Indonesia.

c) Jenis-Jenis Hedonism

1).Hedonisme Psikologis

Hedonisme yang menganggap manusia sebagai yang menginginkan kesenangan. Secara naluri, manusia memang memiliki sifat menghindari rasa sakit dan derita.

2) Hedonisme Evaluatif

Dalam konsep hedonisme evaluatif, hanya kesenangan yang berharga dan rasa sakit atau ketidak senangan dianggap sesuatu yang tidak pantas untuk diterima.

4. Kelebihan hedonisme:

a). Motivasi yang kuat dalam mencapai keinginannya.

b) Pantang menyerah dan menantang. c) Menghargai waktu kesempatan, karena setiap waktu dan kesempatan digunakan untuk mewujudkan yang mereka inginkan.

\section{B. HEDONISME DALAM PANDANGAN ISLAM}

Hedonisme juga bisa muncul dalam kehidupan seorang muslim ketika tujuan hidupnya hanya memperturutkan hawa nafsunya dan tujuannya ingin meraih kesenangan sesaat di dunia ini saja. Hedonisme jelas bertentangan dengan ajaran Islam. Hedonisme tidak mempercayai adanya hari pembalasan, karena kesenangan sudah dapat dinikmati di dunia tidak perlu menunggu di kehidupan berikutnya yang belum jelas. Islam memberi peluang kepada manusia untuk menata kehidupan dunia dengan kemapanan materi. Tapi ingat, dunia bukan tujuan akhir. Dunia adalah "ladang amal" untuk menentukan masa depan seseorang di akhirat kelak. Surga atau neraka adalah pilihan yang kita tentukan di dunia berdasarkan amal.Dalam sebuah firman-Nya ditegaskan, "Maka janganlah sekali-kali kehidupan dunia memperdaya kamu." (QS:. Luqman/31: 33). Allah Swt sudah tegaskan bahwa kehidupan dunia adalah senda gurau dan permainan. Oleh sebab itu manusia harus hati-hati dengan ornamen 
kehidupan dunia. Bagi orang yang bertaqwa kehidupan akhirat itu lebih baik (QS: alAn'am/31: 32).

Epikurus membahas tiga masalah yang mengganggu ketenangan: Pertama, ketakutan akan dewa-dewa. Kedua, ketakutan akan kematian. Ketiga, ketakutan akan masa depan atau nasib. Ketiga masalah init tidak perlu ditakuti, karena dewa-dewa tidak akan mengganggu manusia, ketakutan akan mati tidak perlu ditakuti, karena dengan mati berarti telah selesai masalah. Nasib baik dan buruk tidak ada kaitannya dengan dewa-dewa, nasib hanya ditentukan oleh manusia itu sendiri yang harus berusaha mendapatkan kenikmatan dan meninggalkan kesedihan dan kesusahan. Pandangan hedonisme ini sangat bertentangan dengan ajaran Islam yang meyakini Allah sebagai pencipta dan berhak disembah penentu segala sesuatu terhadap makhluknya. Ketika manusia dalam kesulitan, sedih, berkekurangan manusia harus berusaha menghindari melalui usaha dan berdo'a serta berharap kepada Allah untuk melepaskan, karena hanya Allah satu-satunya yang Maha kuasa dan menentukan.

Ternyata hedonisme tidak menghalalkan semua cara untuk mencapai "kenikmatan" Bagi hedonisme kenikmatan yang menjadi tujuan hidup bukan berarti rakus dan memperbanyak harta semata, tetapi kenikmatan yang bisa menghindari kesulitan dan kepedihan dan inilah yang menjadi tujuan hidupnya. Dalam ajaran Islam memberi kebebasan menjadi penikmat selama tidak melanggar syariat. Sayangnya Epikuros belum mampu memberi aturan dan rambu-rambu tentang cara menikmati sesuatu yang tidak mengakibatkan penderitaan dan kesedihan. Seandainya Epikuros dapat membeir aturan-aturan dalam "menikmati kehidupan dunia" tentu saja paham hedonisme tidak akan menjadi symbol kerakusan, foya-foya, boros yang dijadikan pola hidup sebahagian manusia di zaman sekarang ini.

Di dalam Al-Quran, banyak sekali pembahasan tentang kebahagiaan dalam hidup manusia, baik kebahagiaan dunia yang bersifat sementara terlebih diakhir nanti. Berikut adalah penjelasan Al-Quran tentang kebahagiaan dalam hidup manusia.

\section{Kebahagiaan Akhirat Lebih Utama}

Islam mendudukkan kebahagiaan duniawi bukan sebagai puncak atau tujuan tertinggi dari kehidupan manusia. Manusia yang memperoleh hasil yang diinginkan. Allah menjelaskan dalam Al-Quran tentang keuntunang di akhirat adalah yang lebih baik dan berlipat keuntungan di dunia..

"Dan (Kami buatkan pula) perhiasan-perhiasan (dari emas untuk mereka). Dan semuanya itu bukan tempat lain yang menyenangkan, dunia dan akhirat itu di sisi Tuhanmu adalah untuk orang-orang yang bertakwa. (QS Az Zukruf: 35)

Islam mendudukkan kebahagiaan duniawi bukan sebagai puncak atau tujuan tertinggi dari kehidupan manusia. Manusia yang memperoleh hasil yang diinginkan. Allah menjelaskan dalam Al-Quran tentang keuntunang di akhirat adalah yang lebih baik dan berlipat keuntungan di dunia..

"Barang siapa yang menghendaki keuntungan di akhirat akan Kami tambah untung dan barang siapa yang menghindarkan untung di dunia Kami menerima untung dari untung dunia dan tidak ada yang membutuhkan bahagianpun di akhirat.” (QS Asy-Syura: 20)

2. Kebahagiaan Sejati Menurut Islam adalah di Akhirat

Dalam al-qur'an Allah menjelaskan bahwa kehidupan dunia hanya senda gurau dan mainmain. Memiliki ini berarti kehidupan di dunia hanya sekali lagi suka kita bercanda dan bermain bersama teman atau keluarga. Tidak terasa, waktu sudah habis dan berlalu begitu cepat. Seperti menyambut kehidupan dan kebahagiaan di dunia.

\section{DOI:xxx-}


"Dan tiadalah kehidupan dunia ini senda gurau dan main-main. Dan sesungguhnya akhirat benar-benar nyata, kapan saja mereka tahu. " (QS Al Ankabut: 64)

"Dan carilah pada apa yang telah dianugrahkan Allah kepadamu (kebahagiaan) negeri akhirat dan janganlah kamu melupakan bahagianmu dari kenikmatan dunia dan berbuat baiklah kepada orang lain sebagaimana Allah telah berbuat baik kepadamu dan janganlah kamu berbuat kerusakan.(QS : Al-Qashash/28: 77)

\section{Bentuk Kebahagiaan di Surga}

Bentuk-bentuk kebahagiaan di surga sering kali jarang dinikmati dan diperdalam oleh manusia. Bukan berarti kita mengharapkan surga, karena hanya Allah lah yang berhak untuk memasukkan kita ke surga atau tidak. Akan tetapi jika kita terus berusaha mengingat kebahagiaan surga, maka kita akan merasakan surga dan dunia adalah yang berbeda jauh.

Dunia tidak akan sebanding dengan kebahagiaan yang ada di surga. Semua yang ada di dalam surga tidak ada yang bisa dilepaskan dari dunia yang penuh dengan konsekwensi. Berikut adalah bentuk-bentuk kebahagiaan di surga, menurut informasi AlQuran.

a. Makanan dan Minuman

Di dalam surga termasuk makanan yang terdiri dari buah-buahan. Hal ini tentu saja berbeda dengan dunia yang ingin menambah buah, harus menunggu musim, mengeluarkan uang, atau berusaha untuk menanamnya. Hal ini berbeda dengan di surga, sehingga orang beriman penghuni surga akan mendapat kemudahan dan kemudahan bersama para pasangannya yang suci. Sementara mereka akan kekal di dalamnya, selama dalam kehendak Allah.

Setiap mereka diberi rezeki buah-buahan dalam surga mereka mengatakan:'inilah yang pernah diberikan kami dahulu". Mereka diberi buah-buahan yang serupa dan untuk mereka didalamnya ada istri-istri yang suci dan mereka kekaldidalamnya (QS; Al Baqarah/2: 25)

b. Tempat Tinggal Berupa Istana

Di dunia hanya para pejabat, raja, atau bangsawan saja yang dapat menikmati hidup di istana. Hal ini tidak terjadi jika manusia berada di surga. Orang-orang beriman akan diberikan istana-istana, tanpa harus melihat kaya, karena di sana sudah tidak ada lagi yang diharapkan. Tentu menakjubkan menakjubkan tinggal di sini, karena menguntungkan dan Kemaha Dahsyatan Allah yang menciptakannya sebagia bentuk terima kasih kepada orang beriman

"Maha Suci (Allah) yang jika Dia menghendaki, niscaya Dibuat-Nya bagimu yang lebih baik dari yang demikian, (yaitu) surga-surga yang mengalir sungai-sungai di bawahnya, dan dibuat-Nya (pula) untukmu istana-istana" (QS: Al-Furqaan/25:10)

c. Perhiasan dan Pakaian

Di dunia, dapatkan gelang-gelang emas, mutiara, pakaian bagus, kebutuhan uang, proses panjang, dan usaha yang keras. Namun tidak dengan kehidupan di surga, semuanya diberikan Cuma-Cuma tanpa harus menunggu menjadi orang yang memiliki banyak uang. Semuanya yang Allah berikan pada penghuni surga sebagai balasan atas kesabaran dan perjuangannya selama di dunia. 
"Sesungguhnya Allah memasukkan orang-orang beriman dan mengerjakan amal saleh yang dijual ke surga-surga yang di bawahnya mengalir melalui sungai. Di surga itu mereka memiliki perhiasan dengan gelang-gelang dari emas dan mutiara, dan pakaian mereka adalah sutera" (QS; Al Hajj/22: 23)

d. Penuh Kesyukuran dan Persaudaraan

Di dalam surga, manusia akan mendapatkan persaudaraan antar sesama penghuni surga. Penghuni di tempat yang akan diberi rasa persaudaraan dan kesyukuran atas segala nikmat yang diberikan Allah. Kesyukuran ini adalah bentuk manusia yang telah melakukan misinya di dunia yang sesuai dengan Tujuan Penciptaan Manusia, Penciptaan Manusia, Penciptaan Manusia, Penciptaan Manusia, Konsep Manusia dalam Islam, dan Hakikat Manusia menurut Islam sesuai dengan agama,

e. Gaya konsumsi sangatlah penting, agar seseorang berhati-hati dalam menggunakan kekayaannya atau dalam membelanjakan sesuatu. Al-Qur'an dan hadist memberikan berbagai petunjuk yang jelas agar perilaku konsumsi manusia menjadi terarah dan dijaukan dari sifat hina karena perilaku konsumsinya. Ada tiga prinsip dasar konsumsi yang digariskan oleh Islam. Pertama; prinsip halal, seorang muslim diperintahkan untuk mengkonsumsi sesuatu yang halal dan tidak mengambil yang haram. Sebagaimana firman Allah dalam QS:.Al-Maidah:88) dan (QS: Al-Maidah :3.) Kedua ; prinsip kebersihan dan menyehatkan, Al-Qur'an mengingatkan manusia untuk makan makanan yang baik yang telah Allah anugerahkan kepada manusia.

Sebagaimana firman Allah (QS.: Al-Baqarah:168), (QS: Al-Baqarah: dan (QS.:An-Nahl :114). Ketiga; prinsip kesederhanaan, bahwa manusia haruslah mengambil makanan dan minuman sekedarnya dan tidak berlebihan karena makanan berlebihan itu berbahaya bagi kesehatan.

Prinsip kesederhanaan ini juga berlaku bagi pembelanjaan, orang tidalah boleh berlaku kikir dan boros. Sebagaimana firman Allah dalam (QS: Al-A'raaf: :31), (QS: AlMaidah:87) dan (QS: Al-Furqan:67). (Chaudhry 2012)

Kalau manusia mencintai dan menginginkan kesenangan dunia adalah alami, karena memiliki hawa nafsu. Islam memberi peluang kepada manusia untuk menata kehidupan dunia dengan kemapanan materi. Tapi ingat, dunia bukan tujuan akhir. Dunia adalah "ladang amal" untuk menentukan masa depan seseorang di akhirat kelak. Surga atau neraka adalah pilihan yang kita tentukan di dunia berdasarkan amal.

Dalam sebuah firman-Nya ditegaskan, "Maka janganlah sekali-kali kehidupan dunia memperdaya kamu." (QS: Luqman: 33). Allah Swt sudah tegaskan bahwa kehidupan dunia adalah senda gurau dan permainan. Oleh sebab itu manusia harus hati-hati dengan ornamen kehidupan dunia. Bagi orang yang bertaqwa kehidupan akhirat itu lebih baik (QS. alAn'am: 32).

\section{Cara Islam Menangkal Hedonisme}

a.Kuatkan Iman dan Pengendalian diri

Dorongan untuk menikmati sesuatu muncul dari hawa nafsu yang sulit merasa puas. Cenderung tidak mengenal aturan halal atau haram. Yang dapat mengendalikan hanyalah kekuatan iman seseorang.

b. Bersyukur

harus memperbanyak syukur. Bersyukur kepada Allah berarti menyadari betapa banyak nikmat yang Allah berikan kepada kita. Walau pun dalam keterbatasan materi kita tetap

DOI:xxx- 
harus bersyukur karena ada kenikmatan lain berupa non-materi yang begitu banyak dicurahkan Allah kepada kita hamba-Nya, terutama nikmat iman.

c. Qana'ah.

Qana'ah adalah sikap rela menerima dan selalu merasa cukup dengan apa yang sudah maksimal dilakukan, serta menerima dengan lapang dada hasil yang diperoleh. Qana'ah adalah bagian dari rasa syukur atas nikmat yang diberikan Allah dan merasa puas dengan apa yang didapatkan.

d. Beramal dan Bersedekah

Untuk yang satu ini mungkin terdengar sedikit klise. Beramal dan bersedekah bisa menghindari Anda dari perilaku hedon. Anda akan berpikir bahwa masih banyak orang yang tidak seberuntung Anda dan membutuhkan uluran tangan Anda. Hal tersebut akan membuat Anda berpikir dua kali ketika ingin menghambur-hamburkan uang.

e. Berhati-Hati Dalam Memilih Pergaulan

Kalau sudah salah memilih pergaulan pasti kamu akan terjebak dengan gaya hidup yang hedon. Maka sebelum terjebak dengan gaya hidup yang hedon sebaiknya kamu mulai mempertimbangkan dan selektif dalam memilih teman. Sebab, teman yang baik tentu akan memberikan pengaruh yang baik untuk kehidupanmu dan bukan pengaruh yang buruk.

f. Hidup Sederhana dan jangan Boros

Dengan memulai hidup sederhana, maka seorang anak akan memulai hidup dengan mengutamakan kebutuhan bukan keinginan atau tuntutan nafsu semata. Dengan menanamkan gaya hidup yang sederhana bisa terhindar dari pemborosan atau keserakahan.

g. Fokus Dalam Bekerja

Menanamkan pola pikir untuk bekerja keras dan mendapatkan penghasilan maka dari kerja keras akan lebih menghargai pekerjaan. Dengan demikian membentuk pola pikir, bahwa mencari uang tidak semudah membalikkan telapak tangan.

\section{Cara orangtua mencegah gaya hidup hedonisme pada anak:}

a. Pengawasan media sosial

Media sosial adalah influencer utama. Konten menyuguhkan gaya hidup mewah dan bersenang-senang sedikit banyak menggeser pola pikir remaja bahwa 'kesenangan' menjadi kebutuhan primer setiap orang. Kesenangan seolah jadi hak yang harus mereka dapatkan sehingga banyak remaja melakukan apa saja untuk bisa memberikan kesenangan tanpa memikirkan baik dan buruk serta efek yang ditimbulkan setelahnya. Untuk itu pembatasan dan pengawasan penggunaan media menjadi wajib bagi orang tua.

b. Pertimbangkan soal reward

Pemberian reward atau hadiah penting bagi anak sebagai bentuk apresiasi. Reward dapat meningkatkan motivasi dan kepercayaan diri. Namun, pemberiannya harus mendapat perhatian khusus agar tidak menjadi bumerang bagi anak dan orangtua. Pertimbangkan dengan matang dan usahakan reward diberikan sebanding dengan usaha dan hasil diperoleh anak. Jangan memberikan reward karena sedang tren atau semacamnya. Hindari pemberian barang mewah yang tidak berkaitan sama sekali dengan statusnya sebagai anak dan pelajar. Hilangkan pola pikir memberikan barang mewah dan terkini menjadi suatu kebanggaan bagi orangtua. 
d. Menjadi teladan terbaik

Orangtua harus bijak bergaul dan beraktivitas sesuai perannya sebagai teladan bagi anak. Banyak orangtua justru terjebak kehidupan sosialita demi mendapat label 'ortu gaul'. Tanpa disadari, gaya hidup seperti ini menjadi bibit hedonisme yang ditanamkan orangtua dan suatu saat akan tumbuh pada anak. Tunjukkan pola hidup sederhana, bekerja keras, pantang menyerah, rasa syukur dan hal positif lainnya.

e. Hindari Fasilitas Full service

Memenuhi kebutuhan anak memang kewajiban orangtua. Sebagai bentuk kasih sayang, tak jarang orangtua berusaha keras memenuhi keinginan anak-anaknya. Namun, perlu diingat anak-anak harus menyadari bahwa tidak semua yang mereka inginkan bisa mereka dapatkan. Didik mereka untuk berusaha, menabung atau mengajukan sejumlah syarat tertentu untuk mendapat sesuatu yang mereka inginkan. Mereka harus bisa menyusun skala prioritas antara keinginan dan kebutuhan.

f. Jadikan "berbagi" kegiatan rutin

Berbagi dapat mengasah empati, meningkatkan rasa syukur, dan mereduksi sikap hidup bermewah-mewahan. Tanamkan pemenuhan terhadap kesenangan tidak selalu melakukan hal-hal yang menyenangkan bagi dirinya. Kebahagiaan bisa juga didapatkan dengan mengajar anak berbagi berupa uang dan makanan apa saja. Hal ini dimaksudkan supaya anak tidak menjadi individualistik.

\section{KESIMPULAN}

Paham hedonisme perlu diwaspadai karena dapat berdampak negatif hingga merusak pola hidup masyarakat menjadi rakus dan menghalalkan segala cara untuk mendapatkan kenikmatan yang hanya sesaat, foya-foya,, komsumtif memiliki harta sebanyak-banyaknya dan tidak memperdulikan orang lain. Tujuan hidup adalah menikmati segala sesuatu kesengsaraan, kesedihan dan kekhawatiran harus dihindari. Untuk mendapatkan kenikmatan sudah dapat dinikmati di dunia tidak perlu menunggu di akhir nanti yang belum tentu kejadiannya. Tidak usah takut dengan dewa, karna tidak akan mengganggu manusia.

Pola hidup yang berdasarkan kenikmatan semata tanpa aturan dan batasan akan melahirkan kehidupan yang kacau. Pola hidup yang hanya mengikuti hawa nafsu manusia tidak bisa menikmati kebahagiaan sejati dan tidak akan pernah puas. Menikmati menurut pandangan Islam tidak dilarang selama sesuai dengan syariat Islam. Dorongan hawa nafsu harus dikendalikan, karena kebahagiaan di dunia hanya sementara yang kekal adalah di akhirat. Dankebahagiaan hanya dapat diperoleh dengan memperbanyak berbuat baik di dunia ini dan beramal saleh.

Dengan demikian memberi pendidikan kepada anak sejak dini tentang makna dan tujuan hidup yang sebenarnya di dunia ini. Dengan cara menghindari sifat boros, dan senantiasa berhemat untuk mempersiapkan masa depan.

\section{DAFTAR PUSTAKA}

Albert E. Avey., Handbook in the History of Philosophy. New York: Barnes \& Noble, Inc. 1954. 
Edwards, Paul (ed). The Encyclopedia of Philosophy, volume ketiga. New York:

Macmillan Company \& The Free Press, 1967

Hadiwijono, Harun. Sari Sejarah Filsafat Barat I. Yogyakarta: Kanisius. 1980.

Franz Magnis-Suseno, Etika Dasar; Masalah-masalah pokok Filsafat Moral. Yogyakarta: Kanisius. 1987

Lorens Bagus, Kamus Filsafat. Jakarta: Gramedia. 200.

Magnis-Suseno, Franz. Etika Dasar: Masalah-masalah Pokok Filsafat Moral.Yogyakarta: Kanisius 1987.

Newberry, Paul A. Theories of Ethics. London: Mayfield Publishing Company. 1999. 13 Model Pendekatan Etika. Yogyakarta: Kanisius. 13 Tokoh Etika Sejak Zaman Yunani Sampai Abad ke-19. Yogyakarta:Kanisius. 1997. Simon Petrus L. Tjahjadi, Petualangan Intelektual. Yogyakarta: Petualangan Intelektual. 2004. Newberry, Paul A. Theories of Ethics. London: Mayfield Publishing Company. 1999. 